\title{
Labor Markets and Income Generation in Rural Argentina
}

By

Dorte Verner $^{1}$

World Bank

World Bank Policy Research Working Paper 4095, December 2006

The Policy Research Working Paper Series disseminates the findings of work in progress to encourage the exchange of ideas about development issues. An objective of the series is to get the findings out quickly, even if the presentations are less than fully polished. The papers carry the names of the authors and should be cited accordingly. The findings, interpretations, and conclusions expressed in this paper are entirely those of the authors. They do not necessarily represent the view of the World Bank, its Executive Directors, or the countries they represent. Policy Research Working Papers are available online at http://econ.worldbank.org.

\footnotetext{
${ }^{1}$ I am very grateful to CIET and PROINDER for assistance on data and information on rural Argentina, Robert Schneider, José María Caballero, Estanislao Gacitua-Mario, Elsie Garfield and Jesko Hentschel for invaluable suggestions and comments, Sergio España and Luis Orlando Perez for discussions and information on education and health, and Michael Justesen and Marisa Miodosky for excellent research assistance.
} 


\begin{abstract}
This paper addresses three areas of the rural labor market: employment, labor wages and agriculture producer incomes. Findings show that the poor allocate a lower share of their labor to farm sectors than the nonpoor do, but still around 70 percent work in agriculture, and the vast majority of rural workers are engaged in the informal sector. When examining nonfarm employment in rural Argentina, findings suggest that key determinants of access to employment and productivity in nonfarm activities are education, skills, land access, location and gender. Employment analyses show that women have higher probability than men to participate in rural nonfarm activities and they are not confined to low-return employment. Moreover, workers living in poorer regions with land access are less likely to be employed in the nonfarm sector. There is strong evidence that educated people have better prospects in both the farm and nonfarm sectors and education is a particularly important determinant of employment in the better-paid nonfarm activities. Labor wage analyses reveal that labor markets pay lower returns to poorer than to richer women and returns to education are increasing with increased level of completed education and income level. Moreover, nonfarm income and employment are highly correlated with gender, skills, household size, and education. This analysis also shows a rather heterogeneous impact pattern of individual characteristics across the income distribution, but education is important for all levels of income. Agricultural producer income analyses reveal that producers' income is monotonically increasing with land size and with completed education level, and positively correlated with road access and use of electricity, fertilizer, and irrigation. Finally, farms operated by women are slightly more productive than farms operated by men.
\end{abstract}




\section{Introduction}

The rural sector is important for the macro and micro economy in Argentina. Agriculture and agrobased industry account for 57 percent of all exports, 36 percent of employment, and 18 percent of GDP. The rural poor and nonpoor receive the largest share of their total income - 54 and 68 percent respectively-from agricultural activities such as farming and agricultural labor (Verner 2006). The rural nonfarm sector is also important for income and employment. The poor and nonpoor in dispersed rural areas receive less than 20 percent of their total income from nonfarm employment (Verner 2006). Remittances and transfers account for 27 and 19 percent of the poor and nonpoor's total income, respectively. This information motivates this paper, and it tries to shed some empirical light on income generation and employment in the agricultural and nonagricultural sectors in rural Argentina.

Labor is poor people's most abundant asset and it accounts for the majority of their total income. Nonetheless, the poor are constrained in their labor use in a number of ways: lack of jobs, low wages, and wage discrimination especially for female and indigenous workers. The poverty analysis reveals that many workers in Argentina, particularly those in the informal sector, are poor despite full-time work (Verner 2006). The challenge of creating employment is therefore to increase worker productivity and tighten the labor market for competitive wages to contribute to poverty reduction and wellbeing. Rural income poverty is widespread and deep and it is especially extensive in Northeast and Northwest Argentina. By the income measure of extreme poverty, nearly 40 percent of rural households are in extreme poverty, compared to just over 30 percent in urban areas. ${ }^{2}$ The rural extreme poor account for around 1.2 million people or around 200,000 households (Verner 2006). In rural and urban Argentina, extreme monetary poverty has increased rapidly in the last decade and currently affects around 10.8 million Argentines. This means that around 28.7 percent of the Argentine population did not have sufficient income to buy a minimum basket of food in 2003. Around 15 percent of the extreme poor people in Argentina live in rural dispersed areas.

Rural labor markets are important for poverty reduction in rural Argentina. Employment is key to lifting poor rural families out of poverty. Rural labor markets can be analyzed in many ways. One way is to consider the agricultural and nonagricultural sector or the nonfarm sector. Rural nonfarm employment has been traditionally seen as a low productivity sector, producing low quality goods. The sector, in this view, is expected to shrink as the economy develops and incomes increase. However, recent research shows that the rural nonfarm sector has a positive role in absorbing a growing rural labor force and slowing rural-urban migration. Moreover, the nonagricultural sector contributes to national income growth and in promoting a more equitable distribution of income

\footnotetext{
2 These poverty rate comparisons refer to income poverty because consumption poverty estimates are not available for urban areas. Consumption poverty measures give a better picture of the true status of household poverty in rural areas and therefore consumption poverty rates is used in the rest of the paper unless stated differently.
} 
(Lanjouw and Lanjouw 2001). Lanjouw and Lanjouw also find that the nonagricultural sector is large and growing in developing countries. In Latin America alone 47 percent of the labor force in rural settlements and rural towns are employed in off-farm activities. Moreover, 79 percent of women in the Latin American rural labor force are employed in off-farm activities. In terms of income the rural nonfarm sector is providing more income to the poor than to the nonpoor. Geographic factors are important when analyzing poverty in Argentina. Living in a poor area can make a profound difference to well-being and life prospects. There are large differences in consumption poverty between different regions, with a not-so-straight gradient from south to north. In 2003, the headcount indigence rate in rural areas in Santa Fe in the Pampeana region reached 7.6 percent, nearly a fourth of that in Santiago del Estero in the Northeast region where 29.1 percent were extremely poor (Verner 2006). Chaco in the Northwest region experienced an extreme poverty headcount of 20.7 percent and Mendoza in the Cuyo region of 26.6 percent. The latter finding may surprise the reader, but considering the fact that many agricultural workers face seasonal employment constraints the finding is less surprising. Agricultural workers in for example garlic, wine, and herbs work 4-6 months a year and not continuously.

In dispersed rural areas the majority of the population lives with limited access to basic infrastructure and services. The rural poor are primarily smallholders, sharecroppers, and informal wageworkers that depend on a diverse strategy of income-generating activities in which subsistence production predominates. The varying soil quality and climatic conditions (76 percent of Argentina is arid or semi-arid) explain why crops and livestock of the poor vary across the country. In the precordillera (mountainous areas) goat rearing is the main occupation of farmers. Poor farmers cultivate corn, cotton, wool, tobacco, or sugarcane and, furthermore, in the North pepper and peas are produced. In addition, a few vegetables and fruits are grown mainly for subsistence.

In semi-arid/desert and transition zones, rainfall is scarce and highly irregular, yielding crops of low quality and low income generating capacity. These small farmers lack modern production technology, basic infrastructure to store harvests to take advantage of cyclical price fluctuations, technical assistance to improve productivity, and organized marketing facilities. Family income is therefore highly variable and there is little opportunity for saving. They have very few assets, including education, and they are very vulnerable. 
In order to have a good understanding of the livelihood of the rural poor it is necessary to address their different livelihood strategies. This has crucial importance for policy recommendations. There are at least three types of rural poor livelihood strategies in Argentina: (i) on-farm-agricultural based livelihood-where 15 percent of the total population (16 percent poor) is engaged full time; (ii) off-farm-agricultural and nonagricultural employment and subsidies - where 21 percent of the total population (59 poor) is engaged full time; and (iii) a combination of (i) and (ii) where 65 percent of the total population (53 and 47 percent poor and nonpoor respectively). ${ }^{3}$ Unfortunately, no data for poor rural people in Argentina are available on social capital, access to markets and institutions therefore these areas are not included in the analysis.

Findings from this paper show that the poor allocate a lower share of their labor to farm sectors than nonpoor do, but still around 70 percent work in agriculture, and the vast majority of rural workers are engaged in the informal sector. Employment analyses show that women have higher probability than men to participate in rural nonfarm activities and they are not confined to low-return employment. Moreover, involvement in the nonfarm sector is related to education attainment; as it increases so does the likelihood of being employed in the nonfarm sector. Workers living in poorer regions with land access are less likely to be employed in the nonfarm sector. Labor income analyses reveal that labor markets pay lower returns to poorer than to richer women and returns to education are increasing with increased level of completed education and income level. Moreover, employment analyses show that nonfarm income and employment is highly correlated with gender, skills, household size, and education. Finally, agricultural producer income analyses reveal that producers' income is monotonically increasing with land size and with completed education level, and positively correlated with road access and use of electricity, fertilizer, and irrigation.

The paper is organized as follows. Section 2 presents data and methodologies applied in the following sections. Section 3 addresses the characteristics of rural labor force and Section 4 analyses correlates of farm and nonfarm employment and the likelihood of being employed in the high/low productivity sectors. Section 5 addresses the composition of rural income and Section 6 present the labor income analysis. Section 7 addresses agricultural producer incomes and its determinants. Section 8 concludes. The paper uses the official Argentine statistical classification methods; rural areas are disaggregated into two categories: i) grouped rural areas with under 2,000 inhabitants and ii) dispersed rural areas or open countryside.

\section{Data and Methodology}

This section presents data sources and methodologies used in this paper to analyze rural labor markets in Argentina.

\footnotetext{
${ }^{3}$ Poor households' assets, social capital, access to markets and services, and existing institutions need to be taken into account in order to achieve sustained poverty reduction.
} 


\section{Data}

Argentina does not have a comprehensive household survey that covers both rural and urban areas. Therefore, analyses in this paper are based on available data: urban households survey (EPH) from 1990 to 2003; Censuses (1991 and 2001). The Agricultural Census was sparsely used in this paper, as we could not get access to the micro dataset but only tabulations that were severely inconsistent. Additionally, this paper applies information from a special rural household survey (RHS) undertaken by the World Bank in 2003 in dispersed rural areas. The survey was undertaken in four provinces: Chaco, Santa Fe, Santiago del Estero, and Mendoza and it covers a third of the rural population in Argentina. The RHS includes 441 households. ${ }^{4}$ Data provided by RHS is critical for making informed decision on alleviating rural poverty in Argentina. It is the first time in Argentina's history that a survey of this magnitude has been conducted. ${ }^{5}$

Consumption data in the RHS is measured in broad sense, i.e. it includes selfconsumption and any kind of consumption including clothes, food, rent, gas, etc. The consumption series are developed using the "Guidelines for constructing consumption aggregates for welfare analysis" or LSM135. "The reason for analyzing consumption in this way is that people tend to easier recall what they consume than what they earn. The income measure includes all income sources such as transfers, remittances, selfconsumption, labor income, and production income.

The RHS also includes information on demographics, employment, education, and health for all household members. Furthermore, a special module with agricultural production questions was applied to farming households. The survey was conducted with the aim of assessing the impact of Argentina's 2001 crisis. Fieldwork for the RHS was conducted in the end of 2002 and beginning of 2003. ${ }^{7}$ The survey was collected in the middle of a crisis and, therefore, data reflect the specific and peculiar situation among the rural population at that time. Hence, we do not make predictions or extrapolates the future or the past from the series.

\section{Methodology}

\footnotetext{
${ }^{4}$ To design the sample, a database with the fractions and radius of each department in each province was considered. In each fraction, a random weighted raffle of 8 to 10 sample points, depending on the number of rural people in the province, was conducted. Once the fraction and points sampled were identified the final sample points were defined considering the number of rural inhabitants in each radius.

${ }^{5}$ Previous studies on livelihoods in rural areas used small samples of data, and they, therefore, take more the form of case studies, for example the study of citrus workers or of a geographic area.

${ }^{6}$ Another resent study using this approach is "Panama Poverty Assessment: Priorities and Strategies for Poverty Reduction" (SKU 14716).

${ }^{7}$ In Mendoza information was gathered between the 5th and 30th of December, in Santiago del Estero between the 7th and 19th of December, in Chaco between December 27th and January 15th and in Santa Fe between the 7th and 30th of December.
} 
The analysis of labor market activity is based on a multivariate analysis using probit regression techniques simultaneously for all provinces. Analyses of producer and labor incomes are based on nonlinear ordinary least square (OLS) and quantile regression (QL) techniques. 


\section{Economic model}

The underlying economic model used in the analysis will simply follow Mincer's (1974) human capital earnings function extended to control for a number of other variables that relate to location. In particular, we apply a semi-logarithmic framework that has the form:

$\ln y_{i}=\varphi\left(x_{i}, z_{i}\right)+u_{i}$

where $\ln \mathrm{y}_{\mathrm{i}}$ is the log of earnings or wages for an individual, $\mathrm{i} ; \mathrm{x}_{\mathrm{i}}$ is a measure of a number of personal characteristics including human capital variables, etc.; and $\mathrm{z}_{\mathrm{i}}$ represents location specific variables. The functional form is left unspecified in equation (1). The empirical work makes extensive use of dummy variables in order to catch nonlinearities in returns to years of schooling, tenure, and other quantitative variables. The last component, $\mathrm{u}_{\mathrm{i}}$, is a random disturbance term that captures unobserved characteristics.

\section{Quantile regressions}

Labor market studies usually make use of conditional mean regression estimators, such as OLS. This technique is subject to criticism because of several, usually, heroic assumptions underlying the approach. One is the assumption of homoskedasticity in the distribution of error terms. If the sample is not completely homogenous, this approach, by forcing the parameters to be the same across the entire distribution of individuals may be too restrictive and may hide important information.

The method applied in this paper is quantile regression. The idea is that one can choose any quantile and thus obtain many different parameter estimates on the same variable. In this manner, the entire conditional distribution can be explored. By testing, whether coefficients for a given variable across different quantiles are significantly different, one implicitly also tests for conditional heteroskedasticity across the wage distribution. This is particularly interesting for developing countries such as Argentina where wage disparities are huge and returns to, for example, human capital may vary across the distribution.

The method has many other virtues apart from being robust to heteroskedasticity. When the error term is nonnormal, for instance, quantile regression estimators may be more efficient than least square estimators. Furthermore, since the quantile regression objective function is a weighted sum of absolute deviations, one obtains a robust measure of location in the distribution and, as a consequence the estimated coefficient vector is not sensitive to outlier observations on the dependent variable. ${ }^{8}$

\footnotetext{
${ }^{8}$ That is, if $y_{i}-x_{i}^{\prime} \hat{\beta}_{\theta}>0$ then $\mathrm{y}_{\mathrm{i}}$ can be increasing towards $+\infty$, or if $y_{i}-x_{i}^{\prime} \hat{\beta}_{\theta}<0, \mathrm{y}_{\mathrm{i}}$ can be decreasing towards $-\infty$, without altering the solution $\hat{\beta}_{\theta}$. In other words, it is not the magnitude of the dependent variable that matters but on which side of the estimated hyperplane the observation is. This is most easily
} 
The main advantage of quantile regressions is the semi-parametric nature of the approach, which relaxes restrictions on parameters to be fixed across the entire distribution. Intuitively, quantile regression estimates convey information on wage differentials arising from nonobservable characteristics among individuals otherwise observationally equivalent. In other words, by using quantile regressions, we can determine if individuals that rank in different positions in the conditional distribution (i.e., individuals that have higher or lower wages than predicted by observable characteristics) receive different premiums to education, tenure, or to other relevant observable variables.

Formally, the method, first developed by Koenker and Basset (1978), can be formulated as ${ }^{9}$

$\mathrm{y}_{\mathrm{i}}=\mathrm{x}_{\mathrm{i}}^{\prime} \beta_{\theta}+\mathrm{u}_{\theta \mathrm{i}}=$ Quant $_{\theta}\left(\mathrm{y}_{\mathrm{i}} \mid \mathrm{x}_{\mathrm{i}}\right)=\mathrm{x}_{\mathrm{i}}^{\prime} \beta_{\theta}$

where Quant ${ }_{\theta}\left(\mathrm{y}_{\mathrm{i}} \mid \mathrm{x}_{\mathrm{i}}\right)$ denotes the $\theta^{\text {th }}$ conditional quantile of $\mathrm{y}$ given $\mathrm{x}$, and $\mathrm{i}$ denotes an index over all individuals, $\mathrm{i}=1, \ldots, \mathrm{n}$.

In general, the $\theta^{\text {th }}$ sample quantile $(0<\theta<1)$ of $y$ solves

$$
\min _{\beta}=\frac{1}{n}\left\{\sum_{i: y_{i} \geq x_{i}^{\prime} \beta} \theta\left|y_{i}-x_{i}^{\prime} \beta\right|+\sum_{i: y_{i}<x_{i}^{\prime} \beta}(1-\theta)\left|y_{i}-x_{i}^{\prime} \beta\right|\right\}
$$

Buchinsky (1998) examines various estimators for the asymptotic covariance matrix and concludes that the design matrix bootstrap performs the best. In this paper, the standard errors are obtained by bootstrapping using 200 repetitions. This is in line with the literature.

\section{Characteristics of the Rural Labor Force and Employment}

The rural labor force is highly feminized. Women are highly engaged in the rural labor market in Argentina; 47.6 percent of the rural labor force is women (Table 3.1). The participation of family and unpaid workers is relatively low in Argentina compared to other developing countries.

The skill level of the rural labor force is low in dispersed rural areas. The average years of education of the employed in dispersed rural labor force reached 6.7 years in

seen by considering the first-order-condition, which can be shown to be given as (see Buchinsky 1998) $\frac{1}{n} \sum_{i=1}^{n}\left(\theta-\frac{1}{2}+\frac{1}{2} \operatorname{sgn}\left(y_{i}-x_{i}^{\prime} \hat{\beta}_{\theta}\right)\right) x_{i}=0$.

This can be seen both as a strength and weakness of the method. To the extent that a given outlier represents a feature of "the true" distribution of the population, one would prefer the estimator to be sensitive, at least to a certain degree, to such an outlier.

${ }^{9}$ See Buchinsky (1998). 
2003. The male and female workers that completed at least primary education reached 64.2 percent (Table 3.1 ). Only 8.5 percent of the rural labor force completed secondary school in dispersed rural areas.

\begin{tabular}{lc}
\hline \multicolumn{2}{c}{ Table 3.1: Labor force in Dispersed Rural Areas in Argentina, 2003 (percent) } \\
\hline Gender & 52.4 \\
Male & 47.6 \\
Female & \\
Labor Status & 41.5 \\
Salaried worker & 46.3 \\
Self-employed & 8.4 \\
Employer & 3.7 \\
Family \& Unpaid Workers & \\
Education & 35.7 \\
No Education \& Primary Incomplete & 52.7 \\
Primary Complete & 7.6 \\
Secondary Complete & 3.9 \\
Higher Education Complete & \\
\hline Source: Own calculation based on RHS 2003.
\end{tabular}

Self-employment is widespread in rural areas. Table 3.1 reveals information on the labor status of the rural population. In 2003, self-employed accounted for 46.3 percent of the employed labor force, salaried workers for 41.5 percent, employers for 8.4 percent while unpaid family workers accounted for 3.7 percent.

Agricultural employment has fallen since the early 1990s. According to demographic censuses agricultural employment has roughly fallen by 34 percent from 1991 to 2001. Moreover, agricultural labor markets are highly seasonal in Argentina and, many rural workers are employed only part-time in agriculture.

\begin{tabular}{|c|c|c|c|}
\hline & Male & Female & $\begin{array}{r}\text { Total } \\
\text { Sample }\end{array}$ \\
\hline Industry & 4.2 & 5.8 & 4.4 \\
\hline Services and Commerce & 9.8 & 36.0 & 15.3 \\
\hline $\begin{array}{l}\text { Agriculture and } \\
\text { Livestock }\end{array}$ & 77.1 & 50.4 & 71.6 \\
\hline Public Administration & 3.4 & 6.3 & 4.0 \\
\hline Other Sectors & 5.6 & 1.5 & 4.7 \\
\hline Total & 100 & 100 & 100 \\
\hline
\end{tabular}


Agriculture is still the main employer in dispersed rural areas. In Table 3.2, the economically active population in dispersed rural areas is broken down by sector of principal activity (occupation). In 2003, 71.6 percent of the working population was engaged in agricultural activities, the vast majority in cultivation. Moreover, the greater part was males, 77.1 and 50.4 percent of the rural males and females respectively were employed in agricultural activities (Table 3.2). Turning to rural nonfarm activities, we observe that 4.4 percent of the working age population was primarily engaged in manufacturing, 15.3 percent in services and commerce, and 4.0 percent in the public administration in 2003. ${ }^{10}$ In total, about 28.4 percent of the rural working population was engaged in nonagricultural activities as a primary activity. These estimates are likely to be conservative estimates of the importance of nonagricultural activities because they do not include nonfarm activities that are secondary.

The nonpoor people are slightly more likely to be employed in agricultural activities than the poor and indigent in dispersed rural areas. While 67.6 percent of the working poor are employed in agricultural activities, more than 76 percent of the nonpoor are active in this sector (Table 3.3).

\begin{tabular}{lccc}
\hline \multicolumn{4}{c}{ Table 3.3: Sector of Employment and Poverty Condition } \\
\multicolumn{4}{c}{ Dispersed Rural Areas in Argentina, } \\
\hline & Indigent & Poor & (percent) \\
\hline Industry & 4.7 & 5.4 & 2.9 \\
Services and Commerce & 16.7 & 15.9 & 14.6 \\
Agriculture and Livestock & 71.2 & 67.6 & 76.3 \\
Public Administration & 1.9 & 4.3 & 3.6 \\
Other Sectors & 5.5 & 6.5 & 2.6 \\
\hline \multicolumn{4}{l}{ Source: Own calculation based on RHS 2003. } \\
\hline
\end{tabular}

Considering the distribution of rural labor by status and farm and nonfarm households, the RHS reveals that the majority of household heads of the nonfarm households are salaried workers and a few are self-employed (Figure 3.1). Of the farm households 30 percent of household heads also offer their labor to the market.

\footnotetext{
${ }^{10}$ Unfortunately, there is no employment data sets, annual household surveys, census data, etc. for rural Argentina on rural sector of employment. Therefore, we are not able to compare this information with other sources.
} 
Figure 3.1: Household Activity and Labor Status in Dispersed Rural Areas, 2003 (percent)

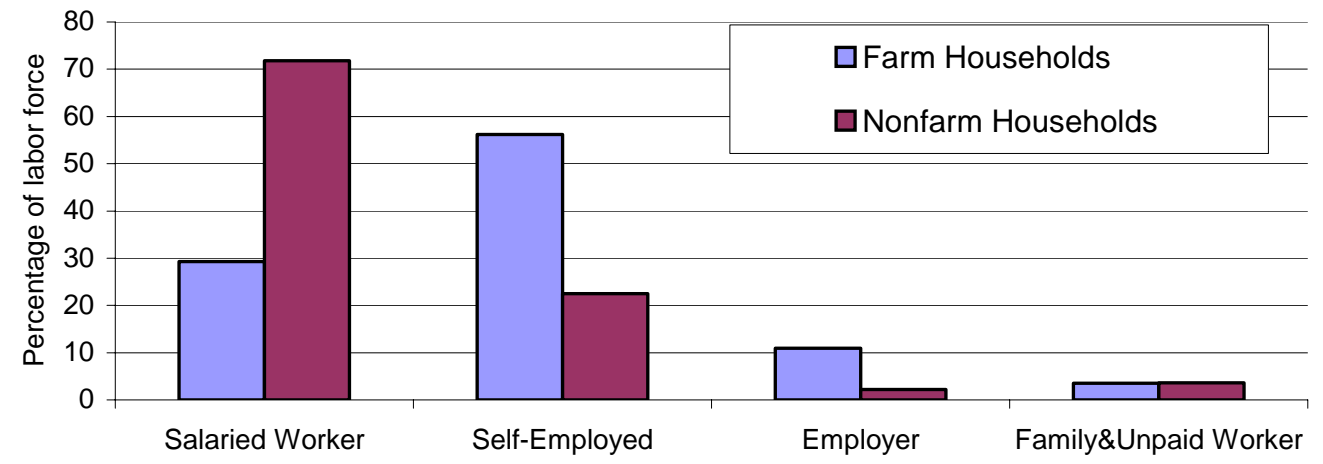

Source: Own calculation based on RHS 2003.

The majority of jobs in dispersed rural areas are informal in nature. The share of the rural workforce engaged in the formal sector is affected by crises and stagnation in production, as these events tend to increase both unemployment and informality. In 2003, only 28.3 percent of Argentina's heads of household in dispersed rural areas was engaged in the formal labor market.

The rural nonfarm sector is very important for income, employment and poverty reduction in Argentina. The significance of rural nonfarm activities is being increasingly recognized in the development literature and in applied programs. ${ }^{11}$ Today's industrialized countries have highly diversified rural areas, with agriculture as only one of many economic activities. Also, rural nonfarm incomes and employment have expanded rapidly in middle income countries. According to Reardon, Berdegué, and Escobar (2001), in the $1990 \mathrm{~s}$, incomes in the rural nonfarm sector accounted on average for around 40 percent of rural incomes in Latin America. In Argentina both the poor and nonpoor receive a large share of their incomes from the rural nonfarm sector; 46 and 32 percent respectively (see below).

The rural nonfarm sector is key to solve a series of issues in rural areas. According to Lanjouw and Lanjow (2001) these are: first, the rural nonfarm sector has a potential to absorb a growing rural labor force; second, the rural nonfarm sector can slow down ruralurban migration; third, the rural nonfarm sector's contribution to national growth; and fourth the rural nonfarm sector can promote a more equitable distribution of income. In the following subsection nonfarm employment and incomes is addressed in more detail.

Rural nonfarm activities account for an important share of employment in rural areas in Argentina. In 2003, about 25 percent of the rural working population declared nonfarm activities as their primary source of employment (see above). These figures are likely to be highly conservative estimates of the importance of RNF activities because they do not take into account seasonality and do not consider secondary occupations. Also, the

${ }^{11}$ See Lanjouw and Lanjouw (2001) and Reardon, Berdegué and Escobar (2001) for two recent surveys. 
figures refer to a definition of rural as disperse areas. Including grouped or semi-urban areas, the share of workers declaring nonfarm activities as their primary occupation would rise significantly. In Mexico, for example the number increases from 44 to 55 percent.

\section{Correlates of Participation in Rural Nonfarm Employment}

What determines what type of workers are most likely to seek employment outside the agricultural sector? This section examines factors, which are associated with employment in nonagricultural activities in dispersed rural areas in Argentina. We present an exercise carried out on the basis of the RNS 2003, using a probit model to determine the probability of individual involvement in non-farm activities as primary occupation, conditional on a range of personal, household and geographical characteristics. The specification of the model draws on findings from the poverty analysis, which suggests that the choice of primary occupation is affected by for example education and gender. Rather than reporting the parameter estimates, which are difficult to interpret on their own, Table 4.1 presents the marginal effects associated with each explanatory variable. These can be interpreted as indicating the effect of a percentage change in the explanatory variable on the probability of involvement in nonfarm business activities, taking all other variables in the specification at their means. ${ }^{12}$ Because of limitations in the RNS survey, some important variables cannot be considered, including ethnicity and social networks.

\footnotetext{
${ }^{12}$ For dummy variables, the marginal effect is calculated as the change in the dependent variable associated with a move from a value of zero for the dummy, to one, holding all other variables constant at mean values.
} 
Table 4.1: Probability of being Employed in the Nonagricultural Sector, Rural Dispersed Areas in Argentina, 2003

\begin{tabular}{|c|c|c|c|c|c|c|}
\hline \multirow[b]{2}{*}{ Worker Characteristics: } & \multicolumn{2}{|c|}{$\begin{array}{l}\text { Nonagricultural } \\
\text { Employment }\end{array}$} & \multicolumn{2}{|c|}{$\begin{array}{l}\text { Low-productivity } \\
\text { Nonagricultural } \\
\text { Employment }\end{array}$} & \multicolumn{2}{|c|}{$\begin{array}{l}\text { High-productivity } \\
\text { Nonagricultural } \\
\text { Employment }\end{array}$} \\
\hline & $\mathrm{dF} / \mathrm{dx}$ & $\mathrm{P}>|\mathrm{z}|$ & $\mathrm{dF} / \mathrm{dx}$ & $\mathrm{P}>|\mathrm{z}|$ & $\mathrm{DF} / \mathrm{dx}$ & $\mathrm{P}>|\mathrm{z}|$ \\
\hline \multicolumn{7}{|l|}{ Education } \\
\hline Primary complete & 0.069 & 0.000 & -0.075 & 0.000 & 0.186 & 0.000 \\
\hline Secondary complete & 0.189 & 0.000 & -0.076 & 0.000 & 0.389 & 0.000 \\
\hline University complete & 0.434 & 0.000 & -0.041 & 0.000 & 0.524 & 0.000 \\
\hline \multicolumn{7}{|l|}{ Skills } \\
\hline Age & 0.010 & 0.000 & -0.003 & 0.000 & 0.002 & 0.000 \\
\hline \multicolumn{7}{|l|}{ Gender } \\
\hline Male & -0.202 & 0.000 & -0.246 & 0.000 & -0.017 & 0.000 \\
\hline \multicolumn{7}{|l|}{ Land } \\
\hline Land per capita & -0.001 & 0.000 & -0.001 & 0.000 & 0.000 & 0.660 \\
\hline \multicolumn{7}{|l|}{ Family characteristics } \\
\hline Family size & -0.013 & 0.000 & -0.013 & 0.000 & -0.003 & 0.000 \\
\hline \multicolumn{7}{|l|}{ Region } \\
\hline Mendoza & 0.055 & 0.000 & -0.033 & 0.000 & 0.102 & 0.000 \\
\hline Santiago del Estero & 0.196 & 0.000 & 0.135 & 0.000 & 0.108 & 0.000 \\
\hline Chaco & 0.288 & 0.000 & 0.172 & 0.000 & 0.187 & 0.000 \\
\hline Pseudos R: & \multicolumn{2}{|c|}{0.118} & \multicolumn{2}{|c|}{0.160} & \multicolumn{2}{|c|}{0.074} \\
\hline
\end{tabular}

Notes: Excluded categories: No education or primary incomplete and Santa Fe.

(1) Low-productivity nonagricultural employment: average monthly nonagricultural labor income is below the poverty line (2) High-productivity nonagricultural employment: average monthly nonagricultural labor income is above the poverty line Source: Own calculation based on RHS 2003.

Findings from above and recent research have shown that the nonfarm sector can often be seen as a source of both high-return employment as well as a "last resort" option (see Ferreira and Lanjouw 2001). Therefore, following Ferreira and Lanjouw, this paper presents estimations of two additional models with the same specification of regressor, but differentiating between high-return nonfarm activities as opposed to low-return nonfarm activities. The nonfarm subsectors are designated as either high return or low return depending on the average monthly earnings accruing to the individuals whose primary occupation is in that sector. If the average monthly labor income is below the poverty line, the sub-sector is designated as low return, or low productivity sector. Conversely, if the average monthly return from a sub-sector is above the poverty line, the sub-sector is designated as high return.

Poor households are often involved in low-return nonfarm occupations. This may be seen as the equivalent of subsistence farming as mentioned by Reardon, Berdegué and Escobar (2001); low productivity, low wage, rather unstable, and with low growth 
potential. These occupations serve as a survival mechanism for poor households with few assets.

Table 4.1 presents three probit models linking the probability of a worker having primary employment in nonagricultural wage-labor occupation to a range of explanatory variables (age, gender, schooling variables, land, household size, and regional dummies) included in the analysis. In the first model, comprising all combined nonfarm activities in dispersed rural Argentina, the dependent variable takes the value of one if the worker is primarily employed in nonagricultural labor and zero if the worker is primarily employed in agricultural labor. The second and third model split those employed in the nonagricultural labor force into two groups; those with a low productivity (low-return) job and those with a high productivity (high-return) job.

Women have considerably higher probability than men to participate in rural nonfarm activities, but men are more likely to be employed in high-return than low-return occupations. Considering all nonfarm employment together, men are significantly less heavily represented in the nonfarm wage-labor force than women, controlling for all other variables (Table 4.1). This finding is different from the poor Northeast Brazil where women are more likely to be represented in the agricultural sector (see Ferreira and Lanjouw 2001), but in line with findings from rural Mexico (Verner 2004). After dividing the types of occupation into two groups depending on whether earnings are lower or higher than the poverty line, men are significantly less likely than women to be employed in lowreturn nonagricultural activities. This is also the case for high-return nonagricultural activities, but the effect is much lower, i.e. the difference between male and female participation rates is leveling out in the high-productivity nonfarm sector. Hence women do not have more limited access to high return occupations and are not confined to low return ones in rural Argentina (which is the case in rural Mexico). However, men are more likely to be employed in high-return than low return nonfarm jobs.

The probability of nonfarm employment rises with increased skill level (proxied by age), controlling for other characteristics. It is positively associated with nonagricultural employment in general and high productivity non-agricultural employment, while it is negatively associated with low productivity nonagricultural employment. Moreover, there is no evidence that participation begins to decline at a certain skill level or age in rural Argentina. This finding contrasts with findings from Brazil where older workers have a smaller probability of being employed off-farm (Ferreira and Lanjouw 2001). However, in rural Argentina the older workers have a smaller probability of being employed in the lowproductivity off-farm sector than do younger workers. This is contrary to what occurred in the high productivity off-farm sector.

Involvement in the nonfarm sector is significantly related to education attainment. As education levels rise, so does the probability of being employed in the high-return sector. Findings in Table 4.1 show that the probability of involvement in the nonfarm sector is positively and significantly related to education levels in rural Argentina. Relative 
to the non-educated, those with education are generally more likely to find employment in the nonagricultural sector, controlling for other variables.

As education attainment rises, so does the probability of being employed in the nonagricultural sector (Table 4.1). In the high productivity jobs, the completed primary, secondary, and tertiary education variables are all statistically significant and positive. At average values of other variables, having completed primary education raises the probability of employment in high-return jobs to 19 percent. Raising the level of attained education to the secondary level increases it even more. A high school educated workers is more than twice as likely to be employed in the high-return nonfarm employment as primary educated workers. Moreover, university graduates have a much larger probability of working in high-return nonfarm jobs than do secondary school graduates (13 percentage points). It is important to acknowledge that the exogeneity of education in these models can be questioned so more research would be needed to understand employment possibilities in high-productive sectors.

Workers with land access are slightly less likely to be employed in the rural nonfarm sector. Access to land is also an important factor to determine sector of labor market participation. In fact, Finan, Sodoulet and de Janvry (2002) find that young educated men from land-poor households in Mexico are more likely to participate in offfarm nonagricultural employment. For Argentina, the regression analysis presented in Table 4.1 reveals that at average values of other variables, increasing the land holding by one hectare reduces the probability of employment in the nonfarm sector and low-return jobs by 0.1 percent, which is very little. However, landholders are not significantly more or less likely to be employed in the high-return rural nonfarm sector than people that are landless.

Workers in regions with higher poverty rates are less likely to participate in rural nonfarm activities. Spatial heterogeneity is large within rural Argentina. Geography influences probabilities of nonfarm sector participation even after controlling for other characteristics. Relative to those living in Santa Fe, workers living in Chaco, Mendoza, and Santiago del Estero are more likely to be employed in high-productive nonagricultural sectors and nonagricultural sectors generally, controlling for individual characteristics. Mendoza's rural-dwellers are less likely than those in the Santa Fe to be employed in lowproductivity nonagricultural activities. This indicates that workers in dispersed rural localities are not stuck with cultivation only as wage employment opportunities do exist. Improving transport infrastructure that provides access to more inhabited rural or urban centers may translate into better access to off-farm jobs. For Mexico, Araujo (2003) finds that interventions in roads are more effective in reducing poverty, through nonfarm rural employment in rural municipalities with low value agriculture outputs, but high productivity of labor.

Rural poor families seem to have benefited from the opportunities opened by the rural nonfarm economy. However, data do not reveal if these opportunities were taken up because of the fall in other sources of income, thus substituting for them, or were an 
addition to these sources. If they were not additional, the conclusion is that they did not serve to reduce poverty.

High return rural nonfarm occupations were mostly taken up by the comparatively better off, however, although the poor have also participated in them to some extent. Hence, it is likely that the impact has not been equalizing, and the rural nonfarm sector has contributed in some measure to the worsening of the rural income distribution. Public and private transfers are a different case. These have definitely helped the poor more than other groups, and have therefore had an equalizing impact.

\section{Wages and Incomes in Rural Areas}

This subsection addresses firstly the levels and sources of wages and income in rural Argentina, secondly determinants of wages and earnings for wage workers, and thirdly determinants of incomes of agricultural producers.

In the longer term, the slowdown in Argentina's rural population growth (see Verner 2006) will affect poverty through its broader effects on the labor market. The population growth experienced in previous decades has resulted in an elastic supply of unskilled labor. Moreover, the type of technical change taking place and crop mix chosen by farmers in Argentina is labor augmenting. As a result wage levels have remained low, except for high skilled, well-educated workers, even in times of relatively high economic growth.

Wages and incomes are key to escaping poverty in rural Argentina as elsewhere. Table 5.1 shows (i) rural farm and nonfarm wages or entrepreneurial earnings and (2) income from public and private transfers. Both are incomes and the former may indicate certain dynamism of the rural economy, while the latter points to an expansion of private and public social protection in rural areas.

Farm income is still the most important income source for rural dwellers in Argentina. The poor and nonpoor in dispersed rural areas receive the largest share of their total income (53.6 and 68.2 percent) from agricultural activities such as farming and agricultural labor (Table 5.1). The rural dwellers also work as laborers in the nonfarm sector; the poor and nonpoor receive 12.8 and 19.8 percent respectively of their total income off-farm. Remittances and transfers are a significant source of income in general in rural areas; accounting for 19 percent of the poor's total income, or 7 percentage points more than the nonpoor that receive 12.8 percent of their total income from these sources. Hence, in total the nonfarm income account for 14 percentage points more of the poor's income than of the nonpoor's income. 
Table 5.1: Households' Income Shares in Dispersed Rural Areas Argentina, 2003 (percent)

\begin{tabular}{lcc}
\hline & Poor & Nonpoor \\
\hline Independent farming & 28.7 & 50.4 \\
Agricultural labor & 24.9 & 17.8 \\
Total agricultural Income & $\mathbf{5 3 . 6}$ & $\mathbf{6 8 . 2}$ \\
Non-agricultural labor & 19.8 & 12.8 \\
Other Sources (transfers and remittances) & 26.6 & 19.0 \\
Total nonagricultural Income & $\mathbf{4 6 . 4}$ & $\mathbf{3 1 . 8}$ \\
\hline Source: Own calculation based on RHS 2003. & & \\
\hline
\end{tabular}

Rural dwellers have a different income source pattern dependent on the region where they live. Figure 5.1 shows that poor and nonpoor households in Mendoza receive the largest share of their income from agricultural labor. For the poor in Mendoza the share of income from farm labor is 139, 249, and 434 percent higher than in Santa Fe, Santiago del Estero, and Chaco respectively. Moreover, rural-dwellers in the poorer provinces receive a much larger share of their income from remittances and transfers than their peers in richer provinces do. Figure 5.1 also shows that independent farming is more important for the nonpoor than for the poor as the share of total income is always higher.

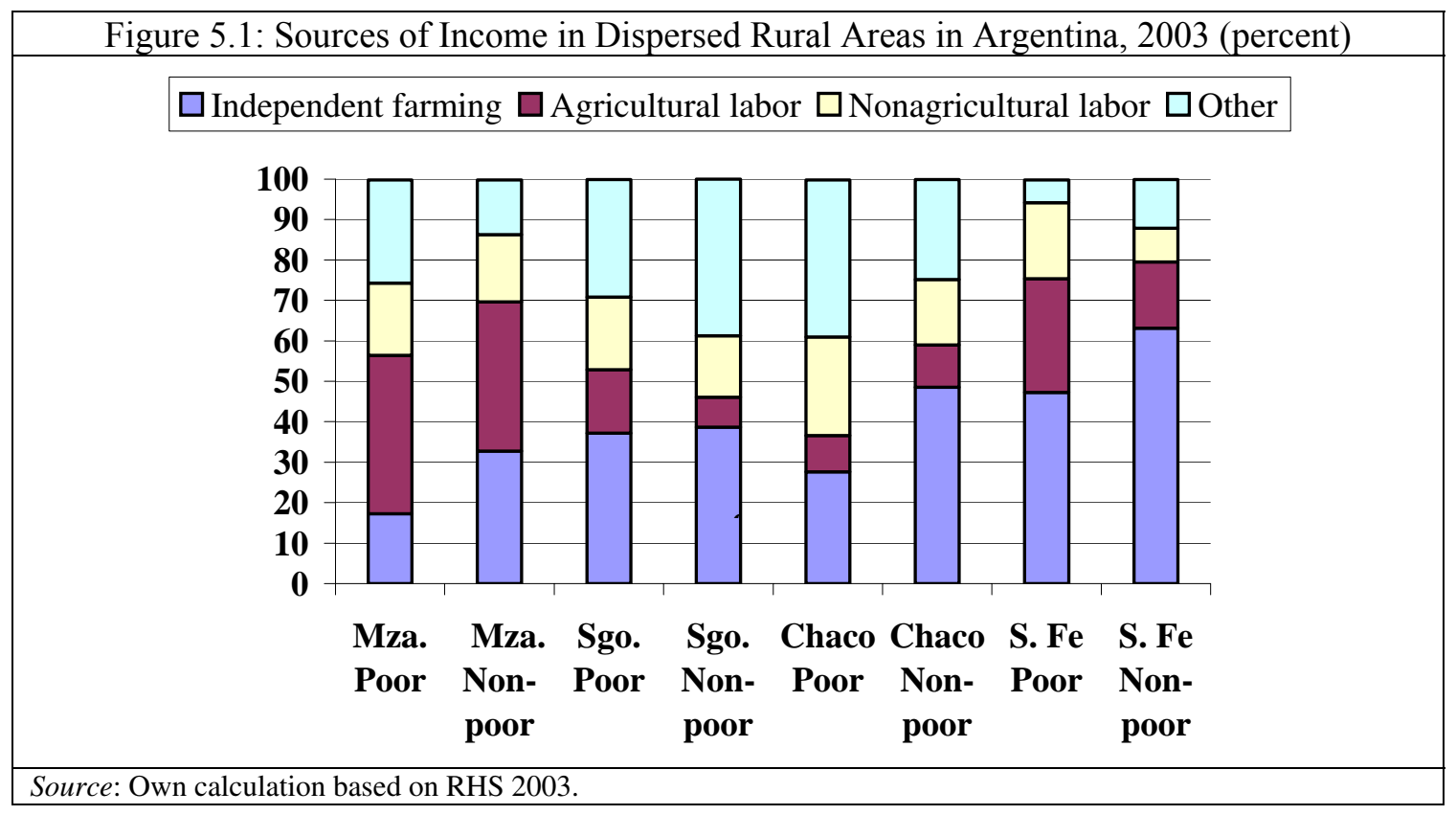

Wages are related to labor status. Formal sector workers, defined as workers that contribute to the pension system, earned more than their peers in the informal sector in 2003. Moreover, permanent workers earn more than temporary workers in dispersed rural areas (Table 5.2). Moreover, employers earn significantly more than self-employed and wage earners in both the formal and informal sector. In the formal sector, employers earn roughly double that of self-employed and four times more than wageworkers. Not only do protected formal sector workers receive benefits in form of pensions, but also average 
wages are significantly higher compared to those of unprotected informal workers. In the informal sector, wages are more aligned (Table 5.2).

\begin{tabular}{|c|c|c|c|c|}
\hline & Permanent & Temporary & Formal & Informal \\
\hline \multicolumn{5}{|c|}{ Total Sample } \\
\hline Self-employed & $4,325.2$ & $1,441.7$ & $7,895.1$ & $2,602.5$ \\
\hline Wageworker & $3,811.4$ & $1,507.7$ & $4,122.8$ & $2,061.8$ \\
\hline
\end{tabular}

Male wages are highest in industry, followed by the public administration and agriculture (Table 5.3). Services pay the lowest wages both to the male and female workers. The highest female wages are paid in the public administration followed by agriculture.

\begin{tabular}{|c|c|c|c|c|}
\hline & & & & \\
\hline & \multicolumn{2}{|c|}{ Male } & \multicolumn{2}{|c|}{ Female } \\
\hline & Wageworkers & $\begin{array}{c}\text { Self- } \\
\text { employed }\end{array}$ & Wageworkers & $\begin{array}{c}\text { Self- } \\
\text { employed }\end{array}$ \\
\hline \multirow{3}{*}{$\begin{array}{l}\text { Agriculture \& } \\
\text { Livestock } \\
\text { Industry }\end{array}$} & $3,018.8$ & $3,283.3$ & $3,742.3$ & $1,174.932$ \\
\hline & & & & \\
\hline & $3,650.4$ & $1,335.8$ & $1,513.9$ & $4,834.8$ \\
\hline \multirow{5}{*}{$\begin{array}{l}\text { Services \& } \\
\text { Commerce } \\
\text { Public } \\
\text { Administration } \\
\text { Other }\end{array}$} & $1,729.5$ & $4,295.5$ & $1,475.6$ & $1,729.5$ \\
\hline & & & & \\
\hline & $3,483.9$ & NA & $4,037.6$ & NA \\
\hline & & & & \\
\hline & $2,258.2$ & $1,649.6$ & $2,400.0$ & 600 \\
\hline $\begin{array}{l}\text { Notes: Exchange } \\
\text { Source: Own cal }\end{array}$ & $\begin{array}{l}\$=3 \text { Argentin } \\
\text { a based on } \mathrm{RH}\end{array}$ & $\begin{array}{l}\text { esos (appr } \\
3 \text {. }\end{array}$ & ation). & \\
\hline
\end{tabular}

Formal sector workers receive not only higher wages than do the informal workers; they also receive benefits. More than half of the formal sector workers receive some form of benefits. Of the individual benefits, bonuses and paid holidays are the most important; 37 percent of the workers receive this benefit.

Child labor still exists in dispersed rural areas of Argentina, but at much lower extent than other countries in the region. International evidence shows that child workers tend to be poor and complete fewer years of schooling than their nonpoor counterparts. Children should not have to work, but an estimated 250 million children are working worldwide. Data reveal that 4 percent of children in Mendoza and Chaco worked in 2003. 
Hence, child labor is not a serious problem in rural Argentina and, furthermore, the majority of children may be both working and studying.

\section{Factors Explaining Rural Labor Income}

After a short and simple presentation of wages and incomes, this section addresses determinants of wages in dispersed rural areas in Argentina. It looks at factors determining rural wages and investigates the characteristics that differentiate low and high paid workers.

Workers located at different points in the wage distribution are compared to analyze this issue, using a quantile regression methodology based on the RHS from 2003. Wages are compared across workers grouped by gender, education, experience, labor status, and location. Findings indicate that wages are by no means determined in the same way for high and low paid workers. For example, female workers are paid much less than males working in the high end of the wage distribution relative to their peers in the low end of the distribution, and returns to lower levels of education are far smaller in the upper income quantiles than in the lower ones.

The quantile regression methodology characterizes the distribution of labor income in more detail than traditional ordinary least squares (OLS) and two stage least squares (2SLS) regressions, as it makes it possible to break down the wage determination process across the entire wage distribution. Specifically, this section addresses the determinants of rural labor incomes of employees and self-employed, including investigations of differences between low and high paid workers (the next section addresses agricultural producer incomes). Comparisons of workers age-14 and older-located at different locations in the labor income distribution shed light on these questions. Labor incomes are compared across workers organized by gender, education, skills, labor status, sector, and location.

Labor incomes are modeled by using log annual labor incomes as the dependent variable. The general model contains explanatory variables in levels and allows for nonlinearities in the data. For example, the log labor income equation is found to be nonlinear in education. In addition, the model contains dummy variables that take the value of one if, for example, a worker holds a job in the formal sector, and zero otherwise. Such a dummy variable may reveal whether there is an income premium related to formal sector employment. The $25^{\text {th }}, 50^{\text {th }}, 75^{\text {th }}$, and $90^{\text {th }}$ quantiles are used in the analysis. Findings indicate that labor incomes are by no means determined in the same way for high and low paid workers. Findings for dispersed rural areas in Argentina are presented in Table 6.1.

All of the included variables are significantly different from zero for all quantiles. Each explanatory variable will now be discussed in turn: education, experience, labor market association and status, sector, gender, and geographical location.

Having completed primary education contributes to better wages, and the premium increases rapidly with the level of education attainment. Better-educated individuals in 
rural Argentina earn much higher wages than their less-educated counterparts. In 2003, the association with the wage level of primary, secondary, secondary, and tertiary education relative to no or incomplete primary education was positive at all quantiles, controlling for other individual characteristics. Compared to the wages of non-educated workers and those with incomplete primary, median wages of workers with complete tertiary education were 136 percent higher; the comparable premium for secondary schooling was 72 percent. Workers with complete primary education received a 27 percent higher return compared to peers with no complete education. ${ }^{13}$

Returns across the wage distribution vary a lot for workers with complete upper secondary and tertiary education; i.e. workers with completed primary education (secondary and tertiary education) in the low end of the income distribution are being paid comparatively less (more) than their peers in the high end. This would seem to indicate that: (1) there is wide heterogeneity in the quality of education in rural areas across the wage distribution, and (2) the capacity of workers to convert their educational capital into higher earnings through labor market networks is not very similar for poorer and richer workers. Hence, poor people with secondary education seem to benefit more from good labor market connections or social networks than richer people. ${ }^{14}$

Workers with complete secondary and tertiary education face decreasing returns across the wage distribution, however: those at the low end are paid proportionally more than those at the high end, indicating that workers with the same level of education are not compensated equally. The poorest (25th quantile) receive a wage premium when completing secondary education of 150 percent, while the richest (90th quantile) receive only 89 percent. One possible explanation is that social networks that facilitate labor market connections operate better among the poorer than the richer segments of the rural labor force.

${ }^{13}$ Recent research shows that returns to education and skills in urban areas of Argentina have increased for all three levels of education in urban areas in the last decade, and it has been more pronounced for tertiary education (World Bank 2004).

14 Hence, workers with the same level of education are not compensated equally. This finding has also been found in the case of blacks in South Africa (Mwabu and Shultz 1996). However, here findings may be due to the fact that there are very few workers in the sample with completed tertiary education and therefore findings cannot be seen as robust. 
Table 6.1: Determinants of Labor Income in Disperse Rural Areas of Argentina, OLS and Quantile Regressions, 2003

\begin{tabular}{|c|c|c|c|c|c|c|c|c|c|c|}
\hline \multicolumn{11}{|c|}{ Dependent variable: Log labor income } \\
\hline & \multicolumn{2}{|c|}{ OLS } & \multicolumn{2}{|c|}{25 th } & \multicolumn{2}{|c|}{50 th } & \multicolumn{2}{|c|}{75 th } & \multicolumn{2}{|c|}{ 90th } \\
\hline & $\begin{array}{c}\text { Return } \\
\%\end{array}$ & $\mathrm{P}>|\mathrm{t}|$ & $\begin{array}{c}\text { Return } \\
\%\end{array}$ & $\mathrm{P}>|\mathrm{t}|$ & $\begin{array}{c}\text { Return } \\
\%\end{array}$ & $\mathrm{P}>|\mathrm{t}|$ & $\begin{array}{c}\text { Return } \\
\%\end{array}$ & $\mathrm{P}>|\mathrm{t}|$ & $\begin{array}{c}\text { Return } \\
\%\end{array}$ & $\mathrm{P}>|\mathrm{t}|$ \\
\hline Age & 0.30 & 0.00 & 0.30 & 0.00 & 1.21 & 0.00 & 0.80 & 0.00 & 1.11 & 0.00 \\
\hline $\begin{array}{l}\text { Female } \\
\text { Education }\end{array}$ & -53.51 & 0.00 & -43.33 & 0.00 & -35.21 & 0.00 & -34.56 & 0.00 & -17.06 & 0.00 \\
\hline $\begin{array}{l}\text { Primary education complete } \\
\text { Secondary education }\end{array}$ & 7.79 & 0.00 & 9.75 & 0.00 & 27.12 & 0.00 & 25.99 & 0.00 & 15.60 & 0.00 \\
\hline $\begin{array}{l}\text { complete } \\
\text { University education }\end{array}$ & 144.49 & 0.00 & 58.57 & 0.00 & 72.12 & 0.00 & 55.89 & 0.00 & 88.89 & 0.00 \\
\hline complete & 353.13 & 0.00 & 192.41 & 0.00 & 135.84 & 0.00 & 92.13 & 0.00 & 52.50 & 0.00 \\
\hline Labor status & 0.00 & 0.00 & 0.00 & 0.00 & 0.00 & 0.00 & 0.00 & 0.00 & 0.00 & 0.00 \\
\hline Has a permanent job & 121.00 & 0.00 & 138.69 & 0.00 & 42.19 & 0.00 & 34.72 & 0.00 & 54.19 & 0.00 \\
\hline Has a formal job & 149.93 & 0.00 & 66.36 & 0.00 & 59.84 & 0.00 & 40.07 & 0.00 & 16.53 & 0.00 \\
\hline Self-employed & -23.43 & 0.00 & -35.60 & 0.00 & -26.36 & 0.00 & 4.50 & 0.00 & 24.23 & 0.00 \\
\hline Wageworker & -16.14 & 0.00 & -5.45 & 0.00 & -3.34 & 0.00 & 12.30 & 0.00 & -7.96 & 0.00 \\
\hline Sector & 0.00 & 0.00 & 0.00 & 0.00 & 0.00 & 0.00 & 0.00 & 0.00 & 0.00 & 0.00 \\
\hline Commerce and Services & -72.11 & 0.00 & -43.62 & 0.00 & -22.59 & 0.00 & -21.96 & 0.00 & -9.06 & 0.00 \\
\hline Agriculture and Livestock & -71.75 & 0.00 & -35.92 & 0.00 & -27.67 & 0.00 & -21.26 & 0.00 & -13.24 & 0.00 \\
\hline Other sector & -13.93 & 0.00 & 2.74 & 0.00 & -15.72 & 0.00 & -15.21 & 0.00 & -9.43 & 0.00 \\
\hline Public Administration & -81.33 & 0.00 & -36.87 & 0.00 & -31.55 & 0.00 & -27.82 & 0.00 & -12.89 & 0.00 \\
\hline Province & & & & & & & & & & \\
\hline Santiago del Estero & -33.44 & 0.00 & -18.37 & 0.00 & -25.40 & 0.00 & -32.23 & 0.00 & -46.74 & 0.00 \\
\hline Chaco & -68.75 & 0.00 & -83.29 & 0.00 & -43.62 & 0.00 & -36.43 & 0.00 & -55.34 & 0.00 \\
\hline Mendoza & -20.23 & 0.00 & 1.82 & 0.00 & -26.36 & 0.00 & -33.77 & 0.00 & -48.93 & 0.00 \\
\hline Constant & 222286 & 0.00 & 103177 & 0.00 & 156612 & 0.00 & 262705 & 0.00 & 436673 & 0.00 \\
\hline $\begin{array}{l}\text { Adjusted R2 (OLS) and Pseudo } \\
\text { R2 (Quantile Regression) }\end{array}$ & 0.13 & & 0.08 & & 0.09 & & 0.10 & & 0.13 & \\
\hline
\end{tabular}

Notes: Excluded categories: no education or primary incomplete, piece-worker, industrial sector, and Santa Fe province. The percentage return is calculated as (exp (coefficient estimate) -1$) * 100$. Number of observations: 514 (weighted: 209,984)

Source: Own calculation based on RHS 2003.

There are several reasons for including experience characteristics in the analysis. One such reason is that a trained and educated workforce provides flexibility in adapting to changes in technology or other economic changes. Experience and years of schooling are widely used in analyses of income determination (see Mincer 1974, and Levy and 
Murnane 1992). The measure of experience included in this analysis is general experience measured by the age of the worker. ${ }^{15}$

General experience - here proxied by the age of the worker-increases wages. Two questions are addressed: (1) is experience important in the wage determination process? and (2) are returns to experience homogeneous across workers? According to the findings presented in Table 6.1, the answer is yes to the first question and no to the second one. The experience variable is statistically significant for all reported quantiles, controlling for other individual characteristics. Returns to experience are low and first increasing and then roughly falling across the income distribution in rural Argentina. Returns to measured annual experience are 0.3 percent in the $25^{\text {th }}$ quantile and 1.2 percent in the $50^{\text {th }}$ and 1.1 percent in the $90^{\text {th }}$ quantile.

Workers in the formal sector obtain a significantly higher pay after controlling for other variables. Labor market association is measured by the formality of a worker's job status. That is, whether a worker is engaged in the formal or informal sector. The positive impact on incomes of formality is decreasing across the distribution; a worker placed in the 25 th quantile obtains an income premium of 66 percent whereas a worker in the 90th quantile and above receives a 17 percent premium. The formal sector generally provides higher quality jobs than the informal one. Since higher quality jobs may require more skills, the informal sector variable may be capturing skill differences not signaled by other variables included in the regression. The wage gap may also be due to lower productivity in the informal sector relative to the formal one not captured by education and experience. Hence, workers in the informal sector are disadvantaged in at least two ways: first, they do not have access to social security; and second, they obtain lower incomes, which evidently do not compensate informal workers for the absence of social security. Informal sector workers are not only disfavored in terms of incomes and social security, but they may also work in an environment where they are more exposed to the risk of accidents occurring and seasonality.

The labor status of workers is another important determinant of wages. All the included occupational groups are statistically significant and different from zero. Looking at the median of the distribution, piece-workers (the reference group) receive 3 percent more than wageworkers do and 26 percent more than self-employed, controlling for other factors such as level of human capital. For the $75^{\text {th }}$ and $90^{\text {th }}$ quantile, the premium-gap changes in favor of the self-employed; the average self-employed earn a 5 and 24 percent premium, respectively. Hence, regarding labor status there exist substantial differences across the income distribution.

Discrimination at an individual level is said to arise if an otherwise identical person is treated differently by virtue of that person's ethnicity or gender, and ethnicity or gender by themselves have no direct effect on productivity. Under perfect competition in the

\footnotetext{
${ }^{15}$ Earlier analyses (not reported in this paper) showed that there are no significant nonlinearities in the data related to age, therefore age is not included squared or in other forms.
} 
capital and labor markets, equivalent employees in equivalent jobs are compensated equally, that is, there is no discrimination.

The estimation of discrimination is difficult. Worker productivity is seldom observed directly, so data must be used to proxy for the relevant productivity characteristics. The main debate occurs over whether relevant omitted characteristics differ between ethnicity, and between gender, and whether certain included characteristics capture productivity differences or instead are a proxy for ethnicity or gender. The following section reports findings on gender differences. Due to lack of data on ethnic origin in RHS, no findings are reported on ethnicity.

Large measurable inequalities persist in rural areas between men and women. Female wages are statistically significant and lower than male wages at all quantiles, controlling for other characteristics. Moreover, findings also suggest that the gender gap is heterogeneous across quantiles, i.e. decreasing across the $25^{\text {th }}-90^{\text {th }}$ quantiles. The largest income gap appears at the lower end $\left(25^{\text {th }}\right)$ of the distribution where women receive around 43 percent lower returns than their male peers. The gap narrows at the top end of the distribution and reaches 17 percent at the $90^{\text {th }}$ quantile.

The gender-earnings gap may, to some degree, be explained by choice of jobs chosen by women. Women are more likely than men to select jobs that are more flexible in nature. For example, women may choose part time jobs or jobs with lower working hours than men. A second factor may be gender differences in unmeasured skills, but they may very well be under capitalized too in terms of experience. Additionally, many women choose professions where they are less forced to capitalize, for example, they work more often in teaching than male peers do. Hence, direct discrimination may be less strong than it appears according to findings presented in Table 6.1 .

In general Santa Fe enjoys a wage premium with respect to the other provinces, i.e. geography matters. In general, workers in dispersed rural areas in Santa Fe are paid significantly more than workers in Chaco, Santiago del Estero, and Mendoza, controlling for other characteristics. However, poorer workers in Mendoza are paid 2 percent more than their peers in Santa Fe, while in Chaco peers are paid 83 percent less. In the top end of the income distribution, workers in Chaco, Mendoza, and Santiago del Estero are being paid 47-55 percent less than their peers in Santa Fe.

\section{The Agricultural Sector and Factors Explaining Agricultural Producer Income}

Agricultural growth can affect poverty through several mechanisms as described in López (2002): higher output of poor farmers, higher wages for unskilled labor, indirect demand for rural non-farm activities, lower food prices, and inter-industry linkages, both upstream, e.g. fertilizers, machines, and downstream, e.g, food-processing industries. Whether agricultural growth is actually poverty reducing will depend on how and where growth takes place, however. 
Argentina is able to produce most field crops at top technical levels. It surpasses the average of the region in all crops mentioned in Table 7.1-except wheat and soybeans which is surprising - and it surpasses Chile in rice and citrus. However, not a single field crop surpasses the USA yield. LAC averages are a modest standard, however, for a middle income country with very favorable natural conditions and a long farming tradition.

\begin{tabular}{lccccccccc}
\hline \multicolumn{1}{c}{ Table 7.1: Crop Yields in Selected Countries, Average 2000-2002, (ton/hectare) } \\
\hline & Mexico & Argentina & Chile & Brazil & LAC & USA & EU & India & China \\
\hline Cereals & 2.8 & 3.4 & 4.9 & 2.9 & 2.9 & 5.8 & 5.6 & 2.3 & 4.8 \\
Maize & 2.6 & 5.8 & 9.8 & 3.0 & 3.0 & 8.5 & 9.1 & 1.9 & 4.7 \\
Wheat & 4.9 & 2.3 & 4.1 & 1.6 & 2.4 & 2.6 & 5.7 & 2.7 & 3.8 \\
Rice & 4.3 & 5.3 & 5.1 & 3.2 & 3.8 & 7.2 & 6.4 & 2.9 & 6.3 \\
Sugar Cane & 74.1 & 65.4 & -- & 69.6 & 64.9 & 77.2 & -- & 67.3 & 61.3 \\
Cotton (Seed) & 3.3 & 1.3 & -- & 2.7 & 2.1 & 1.9 & 3.3 & 0.6 & 3.3 \\
Coffee (Green) & 0.4 & -- & -- & 0.9 & 0.8 & -- & -- & 1.0 & -- \\
Citrus & 12.4 & 20.1 & 15.4 & 22.0 & 17.0 & 34.7 & 18.3 & 17.8 & 8.2 \\
Pulses & 0.8 & 1.1 & 1.6 & 0.7 & 0.8 & 1.9 & 2.7 & 0.6 & 1.4 \\
Vegetables & 16.5 & 17.2 & 25.6 & 17.9 & 14.9 & 27.1 & 26.7 & 12.9 & 19.2 \\
Soybeans & 1.6 & 2.5 & 0.0 & 2.6 & 2.5 & 2.6 & 3.3 & 0.8 & 1.7 \\
\hline \multicolumn{7}{l}{ Source: Caballero (2005)--calculations based on FAO's AGROSTAT. } \\
\hline
\end{tabular}

Labor productivity in Argentina's agricultural sector is the highest in the region and way above the average for LAC countries. Labor productivity is compared across the LAC region in Figure 7.1. Argentina and Uruguay, both land-abundant countries, have the highest labor productivity, with a labor productivity of US\$ 9,461 and US\$7,807, respectively, which is far more than double the LAC average of US\$ 3,368. The high agricultural labor productivity in Argentina are mainly due to factors other than public expenditure in the sector, which are only $\$ 136$ per worker and lower the average for Latin America of US\$ 146 per agricultural worker (calculations made in Caballero 2005). 


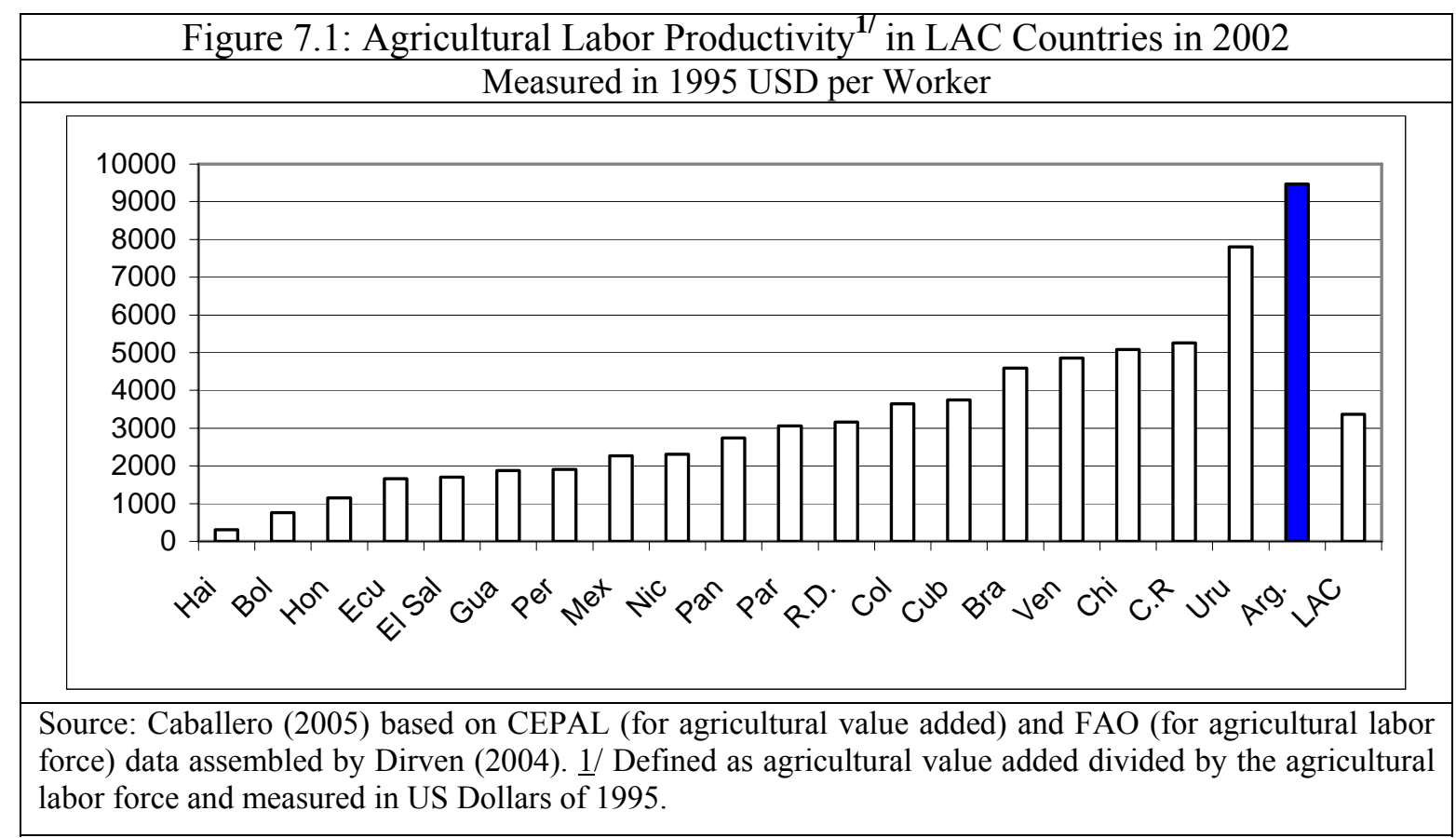

According to an agricultural orientation index Argentina practices expenditure discrimination against the farming sector. The index is constructed by dividing the share of agricultural spending in total spending by the share of agriculture in GDP (Table 7.2). The index measures the intensity of the fiscal effort in agriculture relative to the economic importance of the sector. Argentina has an agriculture orientation index of 0.07, or a fifth of the average of the LAC region (0.33). Argentina, hence, practices public expenditure discrimination against its agriculture.

\begin{tabular}{lc}
\hline $\begin{array}{c}\text { Table 7.2: Public Expenditure in Agriculture as Percentage of } \\
\text { Total Public Expenditure in LAC Countries, Average 1996-2000 }\end{array}$ \\
\hline Brazil & 0.23 \\
Mexico & 1.79 \\
Bolivia & 0.41 \\
Colombia & 0.06 \\
Peru & 0.19 \\
Argentina & 0.07 \\
Chile & 0.37 \\
Costa Rica & 0.12 \\
El Salvador & 0.08 \\
Guatemala & 0.07 \\
Nicaragua & 0.20 \\
Dominican Republic & 0.37 \\
Average LAC & 0.33 \\
\hline Source: Caballero (2005) based on data from Kerrigan (2001). \\
\hline
\end{tabular}


After addressing briefly the agricultural sector as a whole, this sub-section addresses the determinants of producer households' income from farm activities in dispersed rural areas and analyzes whether various individual, sectorial, production, infrastructural, and geographical characteristics are important for the generation of agricultural producer incomes.

Rural producer incomes generated in agriculture are analyzed by applying an augmented earnings function method. Producer incomes from farm activities are modeled by using log annual incomes drawn from farming activities as the dependent variable. The general model contains explanatory variables in levels and allows for nonlinearities in data. Findings are presented in Table 7.3. All included explanatory variables have the expected signs and they all are statistically significantly different from zero. Each explanatory variable will now be discussed in turn: (1) education; (2) gender; (3) farm size; (4) access to infrastructure, and (5) access to production techniques.

Are returns to education for producers in dispersed rural areas constant over different education levels? ${ }^{16}$ According to the findings presented in Table 7.3, the answer is no. Findings allow for comparison of producers with no completed level of education (the reference group) with peers who have completed primary, secondary, and tertiary education. In 2003, returns to primary, secondary, and tertiary education in rural Argentina were statistically significantly different from zero and positive, controlling for other characteristics. Moreover, the premium is rapidly increasing with attained education. In rural Argentina, an average producer experiences an impact on income of 11, 124, and 185 percent for completed primary, secondary, and tertiary education respectively. ${ }^{17}$ Hence, more-educated producers earn significantly higher incomes than do their less educated peers. Given the large difference between returns to completed primary and secondary education, one could suspect that there that some omitted human capital variable is being picked up by education.

\footnotetext{
${ }^{16}$ These rates of return are calculated by the earnings function method due to Mincer (1974).

${ }^{17}$ The percentage return is calculated as (exp(coefficient estimate $\left.)-1\right) * 100$.
} 
Table 7.3: Determinants of Producer Income in Dispersed Rural Areas of Argentina, 2003

Dependent variable: Log Household Farm Income

\begin{tabular}{l|cc} 
& Marginal impact (\%) & $\mathrm{P}>|\mathrm{t}|$ \\
\hline $\begin{array}{l}\text { Gender } \\
\text { Male }\end{array}$ & -7.13 & 0.00 \\
Education & & \\
$\quad$ Primary education complete & 10.96 & 0.00 \\
$\quad$ Secondary complete & 124.34 & 0.00 \\
$\quad$ University studies & 185.48 & 0.00 \\
Land & & \\
2-10 hectares & 100.77 & 0.00 \\
11-35 hectares & 283.44 & 0.00 \\
36-100 hectares & 312.06 & 0.00 \\
101-250 hectares & 877.67 & 0.00 \\
More than 250 hectars & 1880.63 & 0.00 \\
\% rented hectares/ total hectares & 0.10 & 0.00 \\
\% owned hectares/ total hectares & 0.00 & 0.01 \\
\% shared hectares/ total hectares & -1.09 & 0.00 \\
\% occupied hectares/ total hectares & 0.40 & 0.00 \\
Infrastructure and production inputs & & \\
Access to a paved road & 29.30 & 0.00 \\
Access to electricity & 43.48 & 0.00 \\
Use fertilizer & 25.61 & 0.00 \\
Access to irrigation & 28.27 & 0.00 \\
Constant & 63170.23 & 0.00 \\
\hline
\end{tabular}

Adjusted R2: 0.35

Notes: Excluded variables: No education or primary incomplete and 0-1 hectares. The marginal

impact/percentage return is calculated as (exp (coefficient estimate) - 1)*100. Number of observations: 124 .

Source: Own calculation based on RHS 2003.

The size of the producer household's land holdings is also important for the income generated on the farm. The farm size variables are all statistically significant and positive. The regression analysis presented in Table 7.3 reveals that at average values of other variables, income increases with farm size, in a nonlinear fashion. In rural Argentina, an average producer experiences an increase in income of 101, 283, 312, 878 and 1881 percent for holding $2-10,11-35,36-100,101-250$, and 250 or more hectares respectively, compared to farmers with only one hectare of land. Hence larger farms earn dramatically higher incomes than do their counterparts with smaller farms. However, whether the farmland is rented or owned has very little measurable effect on incomes. 
Farms run by women are more productive ( 7 percent) than farms run by men in disperse rural areas (Table 7.3). The dummy variable included for male head of households is negative and significantly different from zero.

Access to infrastructural services is important for income generation in disperse rural areas of Argentina. Farmers with access to paved road and electricity are more productive and earn statistically significantly higher incomes than do farmers without access. Access to paved road or electricity increase income by 29 and 44 percent respectively.

The use of productivity enhancing production techniques such as fertilizers and irrigation are also important for increasing income in rural Argentina. Fertilizer use and access to irrigation are both significantly positive determinants of farm income, although there may be possible endogeneity at play. Farms that apply these productivity enhancing technologies such as irrigation and fertilizers experience 28 and 26 percent higher incomes than farms that do not use or have access to irrigation or fertilizers respectively.

\section{Conclusion}

A comprehensive vision of rural development beyond sectoral approaches is forming. The rural world is not only an agricultural world-although it is more so in Argentina than for example in Mexico - and the rural economy is not only an agricultural economy; indeed, the combination of economic activities is the dominant characteristic of rural households and communities. Unfortunately, the governments in Argentina have still not embraced a more comprehensive view of the rural world, including changing the institutional set up.

The demographic changes and those in the characteristics of the labor force reflect a rural society in transformation - a view reinforced by the increasing extent of migration (see Verner 2006). When examining correlates of nonfarm employment in rural Argentina, findings suggest that key determinants of access to employment and productivity in nonfarm activities are education, skills, land access, location and gender. There is strong evidence that educated people have better prospects in both the farm and nonfarm sectors. This is emphasized when nonfarm activities are divided into low-return and high-return activities. Education is a particularly important determinant of employment in the betterpaid nonfarm activities. Furthermore, the labor income analysis shows a rather heterogeneous impact pattern of individual characteristics across the income distribution. That is, the magnitude of the effect of an income determinant is different depending on the worker being rich, poor or placed in the median of the income distribution. The agricultural producer income analyses reveal that education is also essential for producers to earning higher incomes.

It is key that governments assist in augmenting the human capital of the rural dwellers in more dispersed rural areas so they can improve their productivity. Secondary education has been repeatedly found to be strongly linked to participation in the rural economy, and also to enhance the income obtained from a variety of occupations and 
technical training. This is one more reason to expand the coverage and quality of secondary education in rural areas, in particular for those who are falling behind such as the extreme poor, indigenous groups, and residents of remote areas. Quality is probably as important or more than quality if we want to increase the impact of education.

The agricultural producer income analyses for rural Argentina reveal that farms operated by women are slightly more productive than farms operated by men. Moreover, the size of the producer household's land holdings is important for the income generated on the farm and at average values of other variables, income increases with farm size. As larger farms earn dramatically higher incomes than do their counterparts with smaller farms. However, whether the farmland is rented or owned have very little measurable effect on incomes. Additionally, access to infrastructural services (paved roads and electricity) and use of productivity enhancing production techniques (fertilizers and irrigation) are important for income generation. Farmers with access to paved roads and electricity earn significantly higher incomes than do farmers without access.

Infrastructure and location characteristics are other important correlates of rural nonfarm participation where policy makers can intervene. Road connections, communications, and energy have been shown to be important for the development of the rural economy. The lack of key infrastructural services is systematically associated with lower incomes and employment opportunities. This is another reason why raising the low levels of investment in rural infrastructure, in particular in grouped rural areas, could pay off. Potentially gains from a spatial policy that favor the concentration of investment and services and the establishment of links between these and their rural hinterlands are so far untapped in rural Argentina.

Pursuing rural nonfarm growth should not be seen as an impediment or an alternative to pursuing agricultural development; there are strong synergies between the farm and nonfarm sectors. In signaling the importance of the rural nonfarm sector and advocating for more policy focus on the nonfarm economy, this does not mean that the importance of agricultural development is reduced. There is no contradiction between the development of the farm and non-farm sectors as shown in Lanjouw and Lanjouw (2001). What is needed is a comprehensive rural development policy where farm and nonfarm can coexist and their connections enhance productivity in both sectors.

Poor small farmers need assistance to improve productivity and an important factor would be the presence of extensive and well functioning research and extension, increased access to land, and rural finance systems. Moreover, poorer farmers tend to face more market failures and need to have services like research and extension, as well as rural finance or credit, tailored to their needs. Finally, small farmers and rural poor in Argentina have never received much attention from governments - they are too few and therefore supply few votes. Government expenditure on agriculture and nonagricultural activities is low in Argentina, reflecting the traditional neglect by governments of rural areas, particularly the rural poor and small farmers, despite a fairly strong labor productivity performance of the sector. Hence a rural development strategy is called for that includes 
specific recommendations for small farmers and other poor people. In this regard, PROINDER has demonstrated that: (i) strategies need to be tailored to the regional and local characteristics of the rural poor and that (ii) interventions aimed at increasing the productivity and sustainability of poor small farmers are viable provided that there is institutional support available to them. PROINDER's data suggest that the approach followed has yielded positive results, both in terms of the welfare status of the families participating in the program as well as from the institutional side, with the establishment of the Comisión de Desarrollo Rural and the drafting of provincial rural development strategies.

Finally, in Argentina rural development is a small part of the Ministry of Agriculture. In order to serve other sectors than agriculture a new model is called for with a clear rural strategy or a national policy to address rural issues including rural poverty. ${ }^{18}$ One option is to create a Sub-secretariat or Secretariat of Rural Development, as has been implemented in other countries in the region, for example in Brazil. This together with increased coordination of programs would increase the impacts individual programs can achieve. Moreover, the government should establish clear and efficient mechanisms for NGO collaboration. Emerging NGO consortia provide one mechanism, which should be explored for fostering greater coordination, dialogue, and joint planning with the government.

\footnotetext{
${ }^{18}$ PROINDER has an institution-strengthening component promoting the development of provincial rural development plans and it also encouraged dialogue among main rural development actors in the country to design a national rural development plan. So far, 16 provinces have designed their rural development plans and a national dialogue is taking place at the National Commission for Rural Development, created on the initiative of PROINDER.
} 


\section{REFERENCES}

Aparicio, S. and R. Benencia (Coordinadores), 1999. "Empleo Rural en Argentina: viejos y nuevos actores en el Mercado de trabajo". In Empleo Rural en Tiempos de Flexibilidad, La Colmena, Buenos Aires.

Aparicio, S. and E. Tapella (2002) "Algunos resultados preliminares del monitoreo de subproyectos". Nacional Coordination Unit, PROINDER, Buenos Aires.

Araujo, C., A.de Janvry and E. Sadoulet, 2003. "Measuring the role of social networks on behavior with an application to rural off-farm employment". Department of Agricultural and Resource Economics University of California Berkeley. Mimeo.

Arias, Omar, K.F. Hollack, and W. Sosa, 1999. "Individual Heterogeneity in the Returns to Schooling: Instrumental Variables Quantile Regression Using Twins Data," Mimeo, University of Illinois.

Brondo, A. and C. Luparia, 2001. "La libreta del trabajador rural". In Neimanl G. (Compilador) Trabajo de campo: producción, tecnología y empleo en el medio rural. Ediciones Ciccus, Buenos Aires.

Buchinsky, M., 1998. "Recent Advances in Quantile Regression Models - A Practical Guideline for Empirical Research". In The Journal of Human Resources, Vol. XXXIII, No. 1, pp. 88-126.

Card, D., 1998. "The Causal Effect of Education on Earnings". Forthcoming in Handbook of Labor Economics, Vol. 3, Ashenfelter, O. and Card, D. (eds.).

Caballero J. M. (2005) “ Rural poverty in Mexico”.World Bank, mimeo.

CEDLAS, 2004. "Monitoring the Socio-Economic Conditions in Argentina, Chile, Paraguay and Uruguay: Argentina chapter". Available online at http://www.depeco.econo.unlp.edu.ar/cedlas/monitoreo/pdfs/argentinal.pdf

Craviotti Clara and S. Soverna, 1999. "Sistematización de estudios de casos de pobreza rural”. PROINDER, SAGPyA, Buenos Aires.

Currie, Janet, 2001. "Early Childhood Development Programs." In Journal of Economic Perspectives, 15 (2), pp. 213-38.

Elbers, C., J. Olson Lanjouw, P. Lanjouw and P. G. Leite, 2001. "Poverty and Inequality in Brazil: Estimates from Combined PPV-PNAD Data." World Bank, Mimeo.

Heckman, James, 1999. "Policies to Foster Human Capital." Working Paper No. 7288. MA: National Bureau of Economic Research, Cambridge. 
Finan, F., E. Sadoulet, and A. de Janvry, 2002 "Measuring the Poverty Reduction Potential of Land in Rural Mexico", University of California at Berkeley. Mimeo.

Ferreira, F. and P. Lanjouw, 2001. "Rural Poverty and Nonfarm Employment in Brazil", World Development, 29/3, pp. 509-528.

Forni, Floreal and G. Neiman, 1994. "La pobreza rural en la Argentina" Documento de trabajo $\mathrm{N}^{\circ} 5$, mimeo inédito, CEPA (Comité Ejecutivo para el Estudio de la Pobreza en la Argentina), Ministerio de Economía y Obras y Servicios Públicos, Secretaría de Programación Económica, Buenos Aires.

Foster, Greer, and Thorbecke, 1984. "A class of decomposable poverty measures." In Econométrica, 52, 761-65.

Gerardi Alejandro and C. Cravioti, 2000. "Implicancias del empleo rural no agropeacuario en los hogares de Rio Negro, Mendoza y Santa Fe". SAGPyA - PROINDER, Buenos Aires.

— 2001 . "Ingresos, niveles de pobreza y gasto de hogares rurales en Mendoza, Río Negro y Santa Fe". PROINDER - SAGPyA - PROINDER, Buenos Aires.

— 2003. "La crisis argentina y su impacto en el bienestar de los hogares rurales en zonas dispersa". Mimeo.

Gacitua Mario E., C. Sianes and Q. Wodon, 2001. "Reproductive Health in Argentina's poor rural area". In Measuring and measurement: Combining qualitative and quantitative methods for the analysis of poverty and social exclusion in LA. Washington, DC: World Bank.

Koenker, R. and Basset, G. Jr., 1978. "Regression Quantiles". In Econometrica, Vol. 46, No. 1, pp. 33-50.

Koenker and D’Orey, 1993. "Computing Regression Quantiles”. In Applied Statistics, 36, pp. 383-393, and 43, pp. 410-414.

Koenker, R. and Portnoy, 1997. "Quantile Regression", Office of Research Working Paper, No. 97-0100, College of Commerce and Business Administration, University of Illinois at Urbana-Champaign.

Lanjouw, J. O. and P. Lanjouw, 2001. "The Rural Nonfarm Sector: Issues And Evidence From Developing Countries". In Agricultural Economics 24, pp.1-23. 
Levy, F. and R. J. Murnane, 1992. "U.S. Earnings Levels and Earnings Inequality: A Review of Recent Trends and Proposed Explanations". In Journal of Economic Literature, Vol. 30, pp. 1333-1381.

Mankiw, N.G., Romer, D., and Weil, D.N. 1992. "A Contribution to the Empirics of Economic Growth”. In Quarterly Journal of Economics, Vol. 107, No. 2.

MECON, 1998. "Informe sobre Niveles de Vida en Hogares Rurales de la provincia de San Juan”. Secretaría de Programación Económica y Regional, Buenos Aires.

MECON, 1998. "Informe sobre Niveles de Vida en Hogares Rurales de las provincias de Misiones y Salta”. Secretaría de Programación Económica y Regional, Buenos Aires.

Mincer, J. .1974. "Schooling, Experience and Earnings", NBER Working Paper, New York.

Murmis Miguel, 1996. "Pobreza rural y ocupación: revisión de algunos datos inéditos". In Revista estudios del trabajo N 12.

Mwabu, Germano and T. Paul, Schultz, 1996, "Education Returns Across Quantiles of the Wage Function: Alternative Explanations for Returns to Education by Race in South Africa", American Economic Review, vol. 86 (2), pp. 335-339.

Neiman Guillermo, 2000. "Crecimiento y exclusión. Nuevas y viejas formas de pobreza rural en Argentina”. In Pobres, pobreza y Exclusión social. CEIL 2000.

2003. "Los salarios de los trabajadores comprendidos en el regimen nacional de trabajo agrario" ILO.

Nussbaumer, Beatriz, 2004. "Towards Millennium Development Goals: Migration and Poverty Reproduction in rural Places. Cases of the Chaco Region in Argentina."

Oxford Analytica; http://www.oxweb.com.

PRODERNOA, 2003. "Estudio de base PRODERNOA, provincia de Catamarca. Mimeo.

PROINDER, 2005. Information provided by the Coordination Unit. , 2003. "Estudio de base PRODERNOA", provincia de Formosa. Mimeo.

Schiovani Lidia, 2000. "Aportes de hijas e hijos a las estrategias de vida familiar. Familias pobres urbanas y rurales en la provincia de Misiones".

Taylor, J. E. and A. Yuwez-Naude, 2000. "The Returns From Schooling In A Diversified Rural Economy", American Journal of Agriculture Econ. 82, May. pp. 287-297.

Verner, Dorte 2004. "Rural Poverty in Mexico During 1992-2002", The World Bank, Washington, DC. Mimeo. 
University of La Plata 2004: web page (http:// www.depeco.econo.unlp.edu.ar.

Wiens, Tom 1998. "Rural Poverty in Argentina", World Bank :Washington, DC.

World Bank 2004 "Rural Infrastructure in Argentina: Its Challenges, Key Issues and Options for its Development" Report No. 26271. World Bank :Washington, DC.

2003 “Argentina Crisis and Poverty Assessment”. Report No. 26127-AR World Bank :Washington, DC.

2003. "Inequality in Latin America \& the Caribbean: Breaking with History?" World Bank: Washington, DC.

2001. "Rural Reproductive Health (Misiones, Salta and Santiago del Estero Provinces)". Volume I: Main Report. World Bank :Washington, DC.

— 2001. "Rural poverty reduction in Brazil: Towards an Integrated Strategy". Report Nº 21790-BR Washington, D.C.

— . 2001. "World Development Report 2000/2001.” World Bank, Washington, D.C. . 2000. "Brazil-Critical Issues in Social Security." World Bank, Report No. 19641-BR, Washington DC.

\section{Other sources}

http://www.responde.org.ar

http://www.indec.gov.ar

http:// www.deis.gov.ar

http:// www.me.gov.ar/

http:// www.trabajo.gov.ar/ 